\title{
Librarian Integration in a Four-Year Medical School Curriculum: A Timeline
}

\section{Mark MacEachern , Whitney Townsend , Kristen Young \& Gurpreet Rana}

To cite this article: Mark MacEachern, Whitney Townsend, Kristen Young \& Gurpreet Rana (2012) Librarian Integration in a Four-Year Medical School Curriculum: A Timeline, Medical Reference Services Quarterly, 31:1, 105-114, DOI: 10.1080/02763869.2012.641856

To link to this article: http://dx.doi.org/10.1080/02763869.2012.641856

册Published online: 30 Jan 2012.

Submit your article to this journal $\pi$

Џlll Article views: 561

Q View related articles $₫$

Citing articles: 2 View citing articles 지 


\title{
INFORMATICS EDUCATION
}

\author{
Linda Hasman and Susan LaValley, Column Editors
}

\section{Librarian Integration in a Four-Year Medical School Curriculum: A Timeline}

\author{
MARK MACEACHERN, WHITNEY TOWNSEND, KRISTEN YOUNG, \\ and GURPREET RANA \\ A. Alfred Taubman Health Sciences Library, University of Michigan, Ann Arbor, Michigan
}

\begin{abstract}
The Taubman Health Sciences Library (THL) is integrated in all four years of the University of Michigan Medical School (UMMS) curriculum. Information resources are introduced at strategic points throughout the curriculum so that students receive training at times when they are most likely to need the resource. Most of the core instruction sessions are taught in teams that consist of librarians and UMMS faculty, which provides unique learning opportunities for students. This article describes each THL instruction activity in the four-year undergraduate UMMS curriculum and provides commentary on the overall effectiveness of this integrated approach to instruction.
\end{abstract}

KEYWORDS Curriculum integration, evidence-based medicine, library instruction, medical education

\section{INTRODUCTION}

The Alfred Taubman Health Sciences Library (THL) is well-integrated in several teaching components of the four-year University of Michigan Medical School (UMMS) curriculum. Like many medical curricula, the primary focus

Comments and suggestions should be sent to the Column Editors: Linda Hasman (lmhasman@buffalo.edu) and Susan LaValley (lavalley@temple.edu).

Address correspondence to Mark MacEachern, A. Alfred Taubman Health Sciences Library, University of Michigan, 1135 East Catherine Street, Ann Arbor, MI 48109. E-mail: markmac@umich.edu 
of the first two years of UMMS is on building background and foundational knowledge of medical practice and clinical skills while also introducing students to the clinical environment and providing them with clinical experiences. In the final two years, the focus shifts to furthering clinical education and applying foundational knowledge in clinical settings. During this period, UMMS students rotate through a set of clerkships and take on increasing responsibilities in the clinical care of patients.

The THL is integrated at every significant juncture in the curriculum. THL librarians meet with students multiple times in the first two months of the first year to provide a basic orientation to the library, MEDLINE, and background resources, such as STAT!Ref, MD Consult, and Access Medicine. The librarians provide instruction to all students at an orientation at the beginning of the second year, and see the students again at the outset of the third year. During the third year, THL librarians have mandatory sessions in several clerkships, providing a range of instruction on clinical resources and the systematic review search process. During the fourth year, the librarians meet with students one last time in a virtual session, which concludes the core search-related thread of the curriculum. In addition to this core, THL librarians are integrated in other parts of the curriculum, periodically offering electives, holding office hours, and participating in new and emerging educational paths. In total, the THL medical education team, which comprises three librarian instructors, provides instruction in seven-which may soon increase to ten-courses spread throughout the four-year program.

This column describes every core THL instruction intervention in the UMMS's four-year curriculum (see Table 1) and comments on the overall effectiveness of this integrated approach to instruction. As will become evident, the sessions are designed to address information needs that students are likely to have at various milestones throughout their medical training.

\section{BACKGROUND}

The THL librarians have provided training to UMMS students since the mid-1990s. Prior to 2003, the majority of sessions were orientations that occurred during the first and third years. The first-year orientation prepared students for the University of Michigan information resource environment while the third-year session introduced students to clinical resources. In addition to these early sessions, THL librarians taught individual sessions upon faculty request as part of UMMS courses. On the whole, THL librarians were involved in medical education instruction, but the involvement was less structured and organized than it would later become.

The 2003-2005 era represented a turning point in THL's involvement in medical education. During this time, the Medical School overhauled its curriculum, and as part of the overhaul, the THL and medical education faculty, 
TABLE 1 Taubman Health Sciences Library Involvement in Undergraduate Medical Education (Table is provided in color online.)

\begin{tabular}{|c|c|c|c|c|c|c|}
\hline & First Year & Second Year & \begin{tabular}{|l|} 
Third-Year \\
Orientation
\end{tabular} & $\begin{array}{l}\text { Third-Year Internal } \\
\text { Medicine Clerkship }\end{array}$ & \begin{tabular}{|l|} 
Third-Year \\
Pediatric \\
Clerkship
\end{tabular} & Fourth Year \\
\hline Scheduling & $\begin{array}{l}2 \text { sessions } \\
1: 1 \mathrm{hr} \text { optional (early } \\
\text { August) } \\
2: 2 \mathrm{hr} \text { required (mid- } \\
\text { late August) }\end{array}$ & $\begin{array}{l}12 \mathrm{hr} \text { session } \\
\text { October }\end{array}$ & $\begin{array}{l}12 \mathrm{hr} \text { session } \\
\text { Early May }\end{array}$ & $\begin{array}{l}3 \text { month intervals } \\
\text { beginning in June }\end{array}$ & $\begin{array}{l}\text { month intervals } \\
\text { beginning in June }\end{array}$ & $\begin{array}{l}\text { beginning in } \\
\text { Aug. }\end{array}$ \\
\hline $\begin{array}{l}\text { Session } \\
\text { description }\end{array}$ & $\begin{array}{l}\text { Medical Decision } \\
\text { Making: Patients \& } \\
\text { Populations I }\end{array}$ & $\begin{array}{l}\text { Medical Decision } \\
\text { Making: Patients } \\
\text { \& Populations II }\end{array}$ & $\begin{array}{l}\text { Medical Decision } \\
\text { Making: Patients } \\
\text { \& Populations II }\end{array}$ & $\begin{array}{l}\text { Internal Medicine } \\
\text { Clerkship }\end{array}$ & \begin{tabular}{|l|} 
Pediatrics \\
Clerkship
\end{tabular} & $\begin{array}{l}\text { Advanced } \\
\text { Medical } \\
\text { Therapeutics } \\
\text { (AMT) }\end{array}$ \\
\hline Session Focus & $\begin{array}{l}\text { Foundational } \\
\text { Resources: } \\
\text { Background } \\
\text { information resources, } \\
\text { secondary literature }\end{array}$ & $\begin{array}{l}\text { Evidence-based } \\
\text { Practice } \\
\text { Resources: } \\
\text { Primary vs. } \\
\text { secondary } \\
\text { literature; } \\
\text { systematic } \\
\text { reviews; practice } \\
\text { guidelines }\end{array}$ & $\begin{array}{l}\text { Information } \\
\text { Resources in the } \\
\text { Clinical } \\
\text { Environment: } \\
\text { Drug databases; } \\
\text { practice } \\
\text { guidelines; patient } \\
\text { education } \\
\text { resources; mobile } \\
\text { resources }\end{array}$ & $\begin{array}{l}\text { Information } \\
\text { Resources in the } \\
\text { Clinical } \\
\text { Environment: } \\
\text { PubMed clinical } \\
\text { queries; practice } \\
\text { guidelines; drug } \\
\text { databases; } \\
\text { systematic reviews }\end{array}$ & $\begin{array}{l}\text { Information } \\
\text { Resources in the } \\
\text { Clinical } \\
\text { Environment: } \\
\text { Evaluating } \\
\text { systematic review } \\
\text { quality for use in } \\
\text { clinical practice }\end{array}$ & $\begin{array}{l}\text { Research } \\
\text { Resources: } \\
\text { Finding the } \\
\text { evidence base in } \\
\text { the primary } \\
\text { literature; the } \\
\text { comprehensive } \\
\text { literature search }\end{array}$ \\
\hline MEDUINE & $\begin{array}{l}\text { MEDUINE via Pubmed } \\
\text { MEDUINE via Ovid } \\
\text { + video tutorials } \\
\text { (PubMed \& Ovid } \\
\text { basics; Accessing } \\
\text { E- journals \& MGettt) }\end{array}$ & $\begin{array}{l}\text { Clinical Queries: } \\
\text { Therapy } \\
\text { Systematic } \\
\text { Reviews } \\
\text { Guidelines }\end{array}$ & & $\begin{array}{l}\text { Clinical Queries: } \\
\text { Clinical Studies } \\
\text { Systematic Reviews }\end{array}$ & $\begin{array}{l}\text { PubMed Clinical } \\
\text { Queries } \\
\text { (Systematic } \\
\text { Reviews) }\end{array}$ & $\begin{array}{l}\text { Introduction to } \\
\text { MeSH in } \\
\text { PubMed; } \\
\text { PubMed Clinical } \\
\text { Queries }\end{array}$ \\
\hline Cochrane & & $\begin{array}{l}\text { Cochrane DSR via } \\
\text { Ovid }\end{array}$ & & CDSR (clinical use) & \begin{tabular}{|l} 
CDSR \\
(information \\
evaluation)
\end{tabular} & \\
\hline Guidelines & & $\begin{array}{l}\text { National } \\
\text { Guideline } \\
\text { Clearinghouse } \\
\text { (NGC) } \\
\text { UMHS Practice } \\
\text { Guidelines } \\
\text { ACP-PIER }\end{array}$ & $\begin{array}{l}\text { Dynamed } \\
\text { NGC } \\
\text { ACP-PIER } \\
\text { UMHS PGs }\end{array}$ & $\begin{array}{l}\text { Dynamed } \\
\text { NGC } \\
\text { ACP-PIER } \\
\text { UMHS PGs }\end{array}$ & & \\
\hline Textbooks & $\begin{array}{l}\text { Video tutorial: } \\
\text { Accessing E-books } \\
\text { (Stat!Ref, MDConsult, } \\
\text { AccessMedicine) }\end{array}$ & & & & & \\
\hline $\begin{array}{l}\text { Drug } \\
\text { Databases }\end{array}$ & & & $\begin{array}{l}\text { Micromedex } \\
\text { Facts \& } \\
\text { Comparisons } \\
\text { Natural Standard }\end{array}$ & $\begin{array}{l}\text { Micromedex } \\
\text { Facts \& } \\
\text { Comparisons }\end{array}$ & & \\
\hline $\begin{array}{l}\text { Patient } \\
\text { Education }\end{array}$ & & & $\begin{array}{l}\text { UMHS Patient Ed } \\
\text { site } \\
\text { MEDLINEPlus }\end{array}$ & If time & & \\
\hline Misc. & $\begin{array}{l}\text { Video tutorial: Intro to } \\
\text { the THL homepage } \\
\text { Psychosocial } \\
\text { Databases }\end{array}$ & & $\begin{array}{l}\text { Clinical } \\
\text { Calculators } \\
\text { AccessMedicine } \\
\text { (Diagnosaurus) } \\
\text { AccessSurgery } \\
\text { Mobile Device } \\
\text { Access }\end{array}$ & If time & $\begin{array}{l}\text { DARE } \\
\text { JAMAEvidence }\end{array}$ & $\begin{array}{l}\text { ISI Web of } \\
\text { Science } \\
\text { Scopus } \\
\text { Embase } \\
\text { Google Scholar }\end{array}$ \\
\hline
\end{tabular}


who had already been partnering on instruction for a number of years, continued their partnership to develop new courses with information resource and search-related content. Initially, there was an extended "orientation" session in both the first and third years, but as these sessions developed and new content gaps were identified, THL librarians proactively proposed new courses. In 2005, THL librarians were invited to teach electives in the second year. In 2007 and 2008, THL proposals to add an additional first-year session, a new second-year session, and a session within the third-year Internal Medicine Clerkship were approved, and all three were added to the curriculum. By 2011, THL had become involved in all four years of the curriculum.

There are few reports in the recent literature of libraries becoming longitudinally integrated within a medical school curriculum. Some libraries have reported significant involvement, but not over a full program. ${ }^{1,2}$ The closest equivalent is the Schaffer Library of Health Sciences at Albany Medical College, which has a medical informatics thread that weaves through the four-year medical curriculum in a manner that very much resembles the THL experience. ${ }^{3}$ At Albany, as at the University of Michigan (UM), resources are introduced at strategic points throughout the curriculum so that students receive training at times when they are most likely to need the resource. At UM, this means that content on e-book resources and basic MEDLINE appear very early in the first year. As students approach and enter their third year, the emphasis shifts to clinical resources and to resources that offer evidence syntheses and summaries. In other words, there is a purposeful, orchestrated timeline for when students are to be introduced to particular content and resources, and this timeline is reinforced elsewhere in the curriculum.

\section{FOUR-YEAR EDUCATIONAL TIMELINE}

During the first year, THL librarians are involved in two instruction sessions as part of a Medical Decision Making thread. The sessions are offered to incoming students each year in August. The first is an optional one-hour session that occurs in the first-year orientation. The second, which is a required session, is two hours and occurs two weeks later. Both sessions are hands-on, and because of limits in the number of computers in the lab, each session is offered up to four times. Both sessions are co-taught by THL librarians and the associate dean for Medical Student Education.

This first optional session serves as a basic orientation to online biomedical resources by introducing students to library services, core sources of background information, and Ovid MEDLINE. During the session, students are given an opportunity to explore Ovid MEDLINE within the context of a prescribed clinical case, which stems from a patient presentation the students experience a few days prior. The instructors interact with students during the 
hands-on time, answering questions about the database and the search process. Once the students have found evidence related to the case, the associate dean facilitates a discussion of how the information they found influences their hypothetical clinical decision. An assignment that requires students to compare Ovid MEDLINE and PubMed is distributed at the end of the class and is due in the next session. For those who opt out of this session, the assignment and a series of short videos, which recap the session's content, are available in the course management site.

The second session formally introduces students to PubMed and psychosocial resources, the latter of which is included to prepare students for an upcoming part of the curriculum. The session is built on a clinical case, complete with a thought question that fosters back-and-forth debate among the students and requires them to utilize four nonbiomedical information resources: a scholarly database, a professional association website, a website that ranks highly in a Google search, and MedlinePlus <http://www. medlineplus.gov $>$. The students are directed to search these resources, and after some time, the group comes together to discuss and evaluate the four sources and the students' findings. The session concludes with a librarian-lead discussion of guidelines for medical professionals to consider when evaluating and using information found on the open web. Besides introducing students to PubMed, this session highlights the importance of critical appraisal in the decision-making process.

In the second year, THL librarians and the associate dean for Medical Student Education co-teach a third session for the Medical Decision Making thread, which builds on the two sessions from the previous year. This mandatory session occurs every October and introduces students to resources that target evidence sources near the top of the evidence pyramid, specifically systematic reviews and practice guidelines.

Students arrive at the second-year session having completed an assignment to find answers to questions from two clinical cases in two prescribed resources and one of their choosing. One case lends itself to systematic reviews while the other to practice guidelines. During the assignment debrief, the faculty instructor discusses the clinical ramifications of the students' findings, and the students are polled for responses to questions about strength of evidence and the resource of their choosing. The polls are conducted using the polling software PollDaddy <http://polldaddy.com/ $>$, which offers the instructors immediate feedback on student perceptions of evidence and resource selection, which can then be fed directly back into the discussion, providing the instructors with an opportunity to clarify and/or expand on any problems the poll exposes. After debriefing the assignment, the students are given hands-on time to search resources that are largely new to them-the Cochrane Database of Systematic Reviews, PubMed Clinical Queries, Dynamed, National Guideline Clearinghouse (NGC), University of Michigan Health System guidelines, and ACP-PIER. 
The librarian instructors conclude the session with a short demonstration of these resources, highlighting the important features.

At the start of the third year, THL librarians partner with the associate dean to orient students to clinical resources. This is a mandatory two-hour session that occurs each May, a week before the students begin the clinical phase of their education. In addition, the librarians are integrated in two clerkships, which run on 12-week rotations. Based on student evaluations and anecdotal feedback, this rapid-fire, hands-on, two-hour introduction to clinical resources is by far the most popular of the required library sessions. The faculty instructor provides a brief introduction to resource selection based on question categorization (see Table 2) and then gives the students a series of seven clinical case scenarios organized by information/resource need (e.g., drug databases, practice guidelines, and patient education information). For each case, students are directed to a resource and told they have three minutes to answer the clinical question before reporting back to the group. After the hands-on time, the faculty instructor discusses the clinical significance of their findings. Overall, the students work through eight resources and answer seven clinical questions over the course of two hours. At the end of the session, the librarians quickly demonstrate other clinical tools (e.g., calculators, differential diagnosis tools) and introduce students to the library's Mobile Resources Research Guide < http://guides.lib.umich. edu/healthmobile>.

The third-year Internal Medicine Clerkship session, which is held during the 12-week Internal Medicine Clerkship rotation, requires students to submit a challenging clinical question they encountered recently during the rotation. The instructors review the student-submitted questions and identify four that best illustrate the tools and features of four major categories of resources: primary literature, systematic reviews, practice guidelines, and drug databases. For each of the four clinical questions selected, the students are directed to two resources and given five minutes to answer the question. The faculty instructor leads a discussion about the clinical significance of their findings. Finally, a librarian walks the students through each resource, again highlighting key features and functionalities. This session, which covers four questions in one hour, is designed to mimic real-life clinical environments where clinicians have little time to search for answers. The resources typically covered are Dynamed, ACP-PIER, NGC, Cochrane, Micromedex, Diagnosaurus, and PubMed Clinical Queries.

In contrast to the frenetic pace of the Internal Medicine Clerkship session, the third-year Pediatrics Clerkship session focuses less on finding and more on evaluating information and integrating that information into clinical practice. During the session, students are given a PICO question and asked to search for a relevant systematic review using PubMed's Clinical Queries. Once a relevant review is identified, they are asked to use the DARE (Database of Abstracts of Reviews of Effects) review structure to evaluate it, and 
TABLE 2 Handout Used During Third-Year Clerkship Sessions

Finding Evidence-based Answers to Clinical Questions

\begin{tabular}{|c|c|c|}
\hline I Need: & Example: & Resources to Consider: \\
\hline $\begin{array}{l}\text { An overview of a disease, } \\
\text { condition, or procedure } \\
\text { (background) }\end{array}$ & $\begin{array}{l}\text { What's the difference between } \\
\text { depression and bipolar } \\
\text { disorder? } \\
\text { I have a new patient with sickle } \\
\text { cell anemia; I need an over- } \\
\text { view of this condition. }\end{array}$ & $\begin{array}{l}\text { Textbooks (print or online) } \\
\text { AccessMedicine } \\
\text { MD Consult } \\
\text { STAT!Ref } \\
\text { Dynamed } \\
\text { UpToDate }\end{array}$ \\
\hline Drug information & $\begin{array}{l}\text { What is the pediatric dosage of } \\
\text { erythromycin for strep throat? } \\
\text { What drugs have been approved } \\
\text { by the FDA for the tx of Alz- } \\
\text { heimer's? }\end{array}$ & $\begin{array}{l}\text { MD Consult } \\
\text { Facts \& Comparisons } \\
\text { Micromedex }\end{array}$ \\
\hline $\begin{array}{l}\text { A synthesis of best } \\
\text { practice } \\
\text { recommendations for } \\
\text { disease management }\end{array}$ & $\begin{array}{l}\text { What's the latest on the } \\
\text { management of panic } \\
\text { disorder? } \\
\text { What's the best method of pain } \\
\text { control in children? }\end{array}$ & $\begin{array}{l}\text { Cochrane Database of } \\
\text { Systematic Reviews } \\
\text { PubMed Clinical Queries - } \\
\text { Systematic Reviews } \\
\text { UMHS Clinical Guidelines } \\
\text { National Guideline } \\
\text { Clearinghouse } \\
\text { ACP PIER }\end{array}$ \\
\hline $\begin{array}{l}\text { An answer to a narrow } \\
\text { question not addressed } \\
\text { in the synthesis } \\
\text { resources }\end{array}$ & $\begin{array}{l}\text { In a } 70 \text { year old woman with } \\
\text { primary insomnia and a } \\
\text { previous adverse reaction to } \\
\text { hypnotics, can cognitive } \\
\text { behavior therapy improve } \\
\text { sleep quality and duration? } \\
\text { In a toddler with croup, does } \\
\text { dexamethasone (or other glu- } \\
\text { cocorticoids) reduce symp- } \\
\text { toms better than standard care? }\end{array}$ & $\begin{array}{l}\text { PubMed Clinical Queries - } \\
\text { Clinical Study Category } \\
\text { ACP Journal Club } \\
\text { Database of Abstracts of } \\
\text { Reviews of Effects }\end{array}$ \\
\hline $\begin{array}{l}\text { Information to share } \\
\text { with patients }\end{array}$ & $\begin{array}{l}\text { Where can I find some nutrition } \\
\text { information for my } \\
\text { newly-diagnosed patient with } \\
\text { diabetes? }\end{array}$ & $\begin{array}{l}\text { MedlinePlus } \\
\text { UMHS Patient Education }\end{array}$ \\
\hline
\end{tabular}

Handout is based on "Finding Evidence-based Answers to Clinical Questions - Quickly and Effectively." Dartmouth Biomedical Libraries, 2010. <http://www.dartmouth.edu/ biomed/resources.htmld/guides/ FindingGoodAnswers.pdf >.

then report their conclusions to the class. This session is held during the 12-week Pediatrics rotation.

As part of an Advanced Therapeutics course during the fourth year, students pursue more specialized research interests and undertake a more rigorous research project than they had completed elsewhere in the curriculum. To support the student projects, the librarians provide a one-hour lecture on MeSH, EMBASE, Scopus, Web of Science, and citation 
tracking and analysis. The focus of all previous library sessions, with the exception of the M3 Pediatrics Clerkship, is on finding answers to clinical questions quickly. This session provides the librarians with an opportunity to discuss important resources that to this point have not been systematically introduced and demonstrated to the students. The session, which occurs at regular intervals throughout the year, is a one-hour lecture taught remotely using AdobeConnect.

\section{ADDITIONAL AND FUTURE INVOLVEMENT}

THL librarians are also involved in other areas of the UMMS curriculum. During the first and second years, librarians offer regular office hours and chat sessions to support the Family Centered Experience < http://www.med.umich. $\mathrm{edu} / \mathrm{lrc} / \mathrm{fce} />$ component of the curriculum. Librarians also periodically teach second-year electives, which are courses that run from four to six weeks and can be on any topic of interest to students. In a new pilot "Path of Excellence" program, which supplements the standard curriculum, a THL librarian is lecturing in the Global Health and Disparities Track Lecture Series, creating instructional materials, consulting with students, and collaborating with faculty to develop program activities. Last, THL librarians are also drafting proposals and working with faculty to become integrated in two more Clerkships, Family Medicine and Surgery, and add a second session to the Pediatrics Clerkship. The proposed session for the Family Medicine Clerkship will focus on particularly complex clinical questions that cannot be neatly answered in one resource, while the Surgery and Pediatrics Clerkships will focus on subject specific resources that are not covered elsewhere in the curriculum (e.g., Access Surgery).

\section{DISCUSSION}

One strength of the curriculum is that its content matures with the students. As they enter clinic in their third year, they are receiving extensive training on clinical resources. Initially, the preclinical courses are built on simulated case scenarios, but once the students begin developing their own clinical experiences they are worked into and become the foundation of the sessions. As the students become involved in extensive research projects in the later stages of the curriculum, they begin to receive training that is designed to support these projects.

Another strength is that the majority of the core sessions are co-taught with medical education faculty, which provides students with a clinical perspective they otherwise would not get in such training sessions. The faculty member who is currently the associate dean for Medical Student Education has been heavily involved in these sessions since the beginning, albeit in 
different positions. By collaborating with the associate dean, the team is able to cover, in every core session, the main components of Evidence-based Medicine (EBM), from the search through the clinical decision-making process. More importantly, combining the search with the decision-making process in a single session places the search process nicely within the entire EBM picture. In other words, it seems as though students are better able to understand the importance of searching and appreciate its role within the context of EBM when they are able conduct searches, appraise the evidence, and discuss the salient clinical points of what they found with a fellow clinician all within a one- or two-hour session.

Since the evidence for standalone, isolated sessions is mixed, this integrated curricular approach strikes the authors as ideal. Some studies demonstrate the efficacy of these types of sessions, while others suggest there is minimal growth in skill development over the long term. ${ }^{4-7}$ It is this lack of evidential strength that justifies the repeated reinforcement and application of these skills throughout a four-year curriculum. While the librarians have not measured skill development throughout the curriculum, the integrated approach has been adopted as a way to mitigate the perceived lack of success of isolated sessions. Furthermore, since these sessions focus not only on resource features but also on the types of questions certain resources are best equipped to answer, the sessions are intended to prepare these future clinicians to effectively choose appropriate resources for their clinical questions. $^{8}$

The instructors perceive the sessions to have a positive impact on student learning outcomes. Anecdotally, the sessions are successful. Students often approach the instructors after sessions to express their appreciation, and THL has continued to add new courses over the years, which suggests the sessions are welcomed and appreciated by Medical School faculty. Since the sessions are a part of the UMMS curriculum, the UMMS faculty handles the official assessments and course evaluations. At no point throughout the curriculum does the library distribute its own evaluation forms, relying instead on the feedback gathered from the UMMS evaluations. As with the anecdotal input, the official evaluations are generally positive and have lead to minor content changes in some of the sessions.

\section{CONCLUSION}

This curriculum could not have developed without the tremendous support of and collaboration with Medical School faculty. The curriculum is the Medical School's, and if faculty within the Medical School do not see an educational role for librarians, then developing such an integrated approach to instruction would be a challenging if not impossible task. The THL librarians were fortunate to identify and collaborate with faculty who recognized the 
importance of the librarian skill set and were supportive of their involvement in the curriculum. In addition, THL librarians proactively sought out and proposed potential areas of involvement, submitting course proposals to decision makers. By adopting this approach, THL librarians have been able to transform two one-hour orientations into an integrated curriculum of library sessions in less than a decade.

\section{REFERENCES}

1. Brown, J.F., and Nelson, J.L. "Integration of Information Literacy into a Revised Medical School Curriculum." Medical Reference Services Quarterly 22, no. 3 (Fall 2003): 63-74.

2. Burrows, S.; Moore, K.; Arriaga, J.; Paulaitis, G.; and Lemkau Jr., H.L. "Developing an 'Evidence-based Medicine and Use of the Biomedical Literature' Component as a Longitudinal Theme of an Outcomes-based Medical School Curriculum: Year 1." Journal of the Medical Library Association 91, no. 1 (January 2003): 34-41.

3. Geyer, E.M., and Irish, D.E. "Isolated to Integrated: An Evolving Medical Informatics Curriculum." Medical Reference Services Quarterly 27, no. 4 (Winter 2008): 451-461.

4. Bradley, D.R.; Rana, G.K.; Martin, P.M.; and Schumacher, R.E. "Real-time, Evidence-based Medicine Instruction: A Randomized Controlled Trial in a Neonatal Intensive Care Unit." Journal of the Medical Library Association 90, no. 2 (April 2002): 194-201.

5. Brettle, A. "Information Skills Training: A Systematic Review of the Literature." Health Information and Libraries Journal 20 (suppl 1, 2003): 3-9.

6. Cullen, R.; Clark, M.; and Esson, R. "Evidence-based Information-seeking Skills of Junior Doctors Entering the Workforce: An Evaluation of the Impact of Information Literacy Training During Pre-clinical Years." Health Information and Libraries Journal 28, no. 2 (2011): 119-129.

7. Dorsch, J.L.; Aiyer, M.K.; Gumidyala, K.; and Meyer, L.E. "Retention of EBM Competencies." Medical Reference Services Quarterly 25, no. 3 (Fall 2006): 45-56.

8. McKibbon, K.A., and Fridsma, D.G. "Effectiveness of Clinician-selected Electronic Information Resources for Answering Primary Care Physicians' Information Needs." Journal of the American Medical Informatics Association 13, no. 6 (2006): 653-658.

\section{ABOUT THE AUTHORS}

Mark MacEachern, MLIS (markmac@umich.edu) is a Liaison Services Librarian; Whitney Townsend, MILS (whitneyt@umich.edu) is Liaison Services Librarian and Coordinator, Health Sciences Executive Research Service; Kristen Young, MLIS (kristeny@umich.edu) is a Liaison Services Librarian; and Gurpreet Rana, MLIS (preet@umich.edu) is Global Health Coordinator; all at the A. Alfred Taubman Health Sciences Library, University of Michigan, 1135 East Catherine Street, Ann Arbor, MI 48109. 